Article

\title{
Economy-Wide Effects of Climate Change in Benin: An Applied General Equilibrium Analysis
}

\author{
Femi E. Hounnou ${ }^{1, *}$, Houinsou Dedehouanou ${ }^{1}$, Afio Zannou ${ }^{1}$, Johanes Agbahey ${ }^{2}$ and \\ Gauthier Biaou $^{3}$ \\ 1 School of Economics, Socio-Anthropology and Communication for Rural Development, Faculty of \\ Agronomic Sciences, University of Abomey-Calavi, Cotonou, Republic of Benin; \\ houinsou.dedehouanou@fsa.uac.bj (H.D.); zannou.afio@gmail.com (A.Z.) \\ 2 Department of Agricultural Economics, Humboldt University of Berlin, D-10099 Berlin, Germany; \\ agbaheyj@hu-berlin.de \\ 3 School of Agribusiness and Agricultural Policy, National University of Agriculture, \\ Ketou, Republic of Benin; gauthier.biaou@fsa.uac.bj \\ * Correspondence: hounnou.femi@gmail.com; Tel.: +00229-9614-9481
}

Received: 26 September 2019; Accepted: 12 November 2019; Published: 21 November 2019

check for updates

\begin{abstract}
This research analyzes the economic effects of climate change-induced crop yield losses in Benin. As agriculture is a large sector in Benin, the climate change-induced crop yield losses are expected to affect the entire economy as well as household welfare in both rural and urban areas. The paper applies a dynamic general equilibrium model and simulates productivity shocks in the agricultural sector derived from climate change scenarios for Benin. The findings show that climate change-induced crop yield losses reduce domestic agricultural outputs by $4.4 \%$ and the nonagricultural output by $0.9 \%$ on average by 2025 . While export supply decrease by $25.5 \%$, import demand increases by $4.9 \%$ on average by 2025 . As price of labour and capital decline, household income drop for all household groups by $2.5 \%$ on average. Ultimately, household welfare decline for all household groups by $2.7 \%$ on average. Rural and particularly poor households are projected to experience the worst adverse effects of climate change-induced crop yield losses. The results show that without adaptive strategies to cope with climate change, economic growth and household welfare will decline even further by 2035 and 2045. Subsequently, the paper suggests that adaptation strategies are needed not only at the national level to overcome the projected negative effects on macroeconomic indicators, but also at household level to enhance the adaptative capacity of households, especially the poor households living in rural areas.
\end{abstract}

Keywords: climate change; dynamic computable general equilibrium; economic effects; food crop yield losses; household welfare; Benin

\section{Introduction}

Climate change is a serious threat to the development of several regions in the world, due to both its economic and biophysical effects [1-3]. As these effects become more tangible, several experts argue that more and frequent extreme weather events are to be expected in the future [2]. The implications of such extreme weather events for economic activities, especially the agriculture and food sector have been investigated at the global level [4,5]. These studies showed that climate change drives crop yield losses and drops in agricultural and food production. Hence, prices for agricultural and food products rise, affecting household welfare. Economies relying on rainfed agricultural systems are the most negatively affected due to rises in temperature, erratic precipitation patterns, and increases in potential evapotranspiration [6-8]. While at global level, the effects and mechanisms are known, more studies are needed at the country level, incorporating local specificities in analyses in order to inform policy. 
In Benin, previous studies showed that yields of major food crops are likely to decline with implications for food security, farm incomes, and household welfare $[8,9]$. The high potential impact of climate change in Benin is due to the size of the agricultural sector in the economy. As of 2016, agriculture accounts for $23 \%$ of the Benin national GDP, $83 \%$ of total merchandise exports, and $41 \%$ of total employment [10]. Hence, the disruptive effects of climate change in the agricultural sector are felt beyond that sector in the entire economy. There are both direct and indirect effects of climate change on the agricultural sector. Direct effects include changes in agricultural outputs. Indirect effects encompass commodity and factor price changes affecting ultimately household incomes and expenditures.

In this paper, the economy-wide implications of climate change in Benin are analyzed and quantified. While vulnerability and adaptation aspects of climate change have been studied in Benin [11-13], little is known about its economy-wide effects. In order to capture these effects, the study employs a single-country computable general equilibrium (CGE) model. The CGE framework allows to examine the interdependent links between supply and demand of agricultural products, on the one hand, and between agricultural markets and the rest of the economy, on the other hand [14]. The remainder of this paper is structured as follows: Section 2 presents the existing literature on the economy-wide effects of climate change, while Section 3 describes the model and illustrates how food crop yield losses are simulated in the model. Section 4 outlines the simulation results, Section 5 discusses these results, and Section 6 provides some concluding remarks.

\section{Reviews of CGE Models and Economy-Wide Effects of Climate Change}

The assessment of climate change-induced economy-wide effects requires the analysis of the various links between climate and economic activities [6]. To capture these effects, the computable general equilibrium model offers the possibility to track the individual effects of an external shock (e.g., climate change scenarios) on the entire economy.

In previous research papers, evidence of climate change was given [7] and induced food crop yield losses were demonstrated [8] in Benin. It was predicted that temperature increases will negatively affect agricultural production [9]. In the developing countries, such as Benin, where rainfed agriculture that is highly subject to climate change effects is a large economic sector, previous studies by Shiferaw et al. [15], Brown et al. [16], and Sadoff et al. [17] using panel data showed a strong correlation between precipitation and/or temperature on the one hand, and economic output and per capita GDP at national and global levels on the other hand. However, such an econometric analysis only captures the direct effects of climate change, while the economy-wide effects are missing. Moreover, most of those studies suffer from data issues over a sufficient period of time or gaps in the series, thus limiting their validity [18]. To evaluate the economic side of climate change effects, other studies used CGE models, which are more appropriate to investigate the economy-wide effects. Table 1 summarizes some studies using the general equilibrium model to evaluate the economic effects of climate change.

Based on this literature review, no CGE application has to our knowledge investigated the assessment of the economy-wide effects of climate change in Benin. Subsequently, this paper contributes to the body of literature by providing such assessment using a model that has been adjusted to replicate the conditions of the Benin economy. The next section describes the model. 
Table 1. Review of climate change effect analysis based on CGE models.

\begin{tabular}{|c|c|c|c|}
\hline Authors & Country & Method & Results \\
\hline Bezabih et al. [19] & $\begin{array}{l}\text { Tanzania } \\
\text { 2020-2080 }\end{array}$ & $\begin{array}{l}\text { A recursive dynamic } \\
\text { CGE Model }\end{array}$ & $\begin{array}{l}\text { In spite of agricultural productivity losses due to } \\
\text { climate change effects, the authors found that the } \\
\text { negative effects were limited and could be justified } \\
\text { by substitution effects in the factor markets. }\end{array}$ \\
\hline Arndt et al. [18] & $\begin{array}{l}\text { Ghana } \\
\text { 2007-2050 }\end{array}$ & $\begin{array}{l}\text { Recursive dynamic } \\
\text { CGE Model }\end{array}$ & $\begin{array}{l}\text { According to the authors, climate change was } \\
\text { projected to reduce national welfare. Poor and } \\
\text { urban households and the northern Savannah zone } \\
\text { could be negatively affected. An equal distribution } \\
\text { of climate effects in terms of size, sectors, and } \\
\text { scenarios was also observed. }\end{array}$ \\
\hline $\begin{array}{l}\text { Ananda and } \\
\text { Widodo [20] }\end{array}$ & Indonesia & Dynamic CGE Model & $\begin{array}{l}\text { According to these authors, GDP and wealth were } \\
\text { negatively affected in the different scenarios. The } \\
\text { more intense the climate change effects are, the } \\
\text { more GDP, welfare, and other macroeconomic } \\
\text { variables decline. They added that the effects were } \\
\text { unequal among households. }\end{array}$ \\
\hline $\begin{array}{l}\text { Boccanfuso et al. } \\
{[21]}\end{array}$ & $\begin{array}{l}\text { Senegal } \\
2013\end{array}$ & $\begin{array}{l}\text { Integrated CGE } \\
\text { Model with a } \\
\text { Microsimultion } \\
\text { Model }\end{array}$ & $\begin{array}{l}\text { The authors claimed that an increase in the world } \\
\text { price of fossil fuels will lead to an increase in } \\
\text { poverty rates. Addingland productivity losses to } \\
\text { increases in the world price of fossil fuels leads to } \\
\text { higher increases in poverty rates. }\end{array}$ \\
\hline $\begin{array}{c}\text { Thurlow et al. } \\
\text { [22] }\end{array}$ & $\begin{array}{c}\text { Zambia } \\
2025\end{array}$ & $\begin{array}{l}\text { Hydro-crop }(\mathrm{HC}) \\
\text { Models and Dynamic } \\
\text { CGE Model }\end{array}$ & $\begin{array}{l}\text { The authors found that GDP declined by } 4 \% \text { and } \\
2 \% \text { of the households fall under the poverty line } \\
\text { because of the climate change effects. }\end{array}$ \\
\hline $\begin{array}{l}\text { Gebreegziabher } \\
\text { et al. [23] }\end{array}$ & $\begin{array}{l}\text { Ethiopia } \\
\text { 2010-2016 }\end{array}$ & Dynamic CGE Model & $\begin{array}{l}\text { The authors showed that agricultural productivity } \\
\text { losses resulting from the climate change effects } \\
\text { lead to income drops. }\end{array}$ \\
\hline Juana et al. [24] & $\begin{array}{l}\text { South } \\
\text { Africa }\end{array}$ & Static CGE model & $\begin{array}{l}\text { The authors demonstrated that precipitation } \\
\text { shortage due to climate change led to a general } \\
\text { deterioration in households' welfare, with the poor } \\
\text { more adversely affected. }\end{array}$ \\
\hline Vista [25] & Philippines & Static CGE model & $\begin{array}{c}\text { The authors found that climate change negatively } \\
\text { affects the real GDP, export quantity, import } \\
\text { quantity, and employment. }\end{array}$ \\
\hline
\end{tabular}

Source: Authors' own compilation.

\section{Methods}

\subsection{The CGE Model}

CGE models are logico-deductive models that derive implications about the behavior of markets, in response to exogenous shocks, based on economic theory in a controlled environment. These models capture the complexity of the interactions between ALL markets in an economy, while allowing users to identify and disentangle the causal factors that generate the implications. The CGE model assumes that consumers maximize utility subject to budget constraints, while the producers maximize profit subject to resource constraints and to production technology or minimize the production costs. The model is based on the neoclassical theory. The model explains all flows of money contained in the social accounting matrix (SAM) as the reference situation, named model calibration. From this point, the model may reset another equilibrium level representing the state of the economy after shock effects (e.g., policy changes, trade liberalization, national sectoral output losses, and change in income or sale taxes). The behavior of different agents or institutions are expressed by a mix of 
linear and non-linear equations. Domestic agents-activities, households, (incorporated business) enterprises, governments, and investments-consume composite aggregates of domestic and imported commodities based on a constant elasticity of substitution (CES) formulation [26]. The distribution of domestically produced commodities among domestic demand and exports is governed by relative prices in these markets, using constant elasticity of transformation (CET) functions, which reflect imperfect product transformation. Government spending is an exogenous variable, non-government institutions are all price takers, and all markets (of commodity and factor) are assumed to clear i.e., demand equals supply. The constraints are expressed through various equations referring to market equilibriums and macro-economic closures (constraint on the government, current account, savings-investments, and the rest of the world) that must be satisfied solving simultaneously all equations in the model.

In this paper, the effects of climate change-induced crop yield losses on the economy of Benin during the period from 2013 to 2045 are simulated. A recursive dynamic computable general equilibrium model is used. This model is based on a static version by Thurlow [27], which is updated for each year within the projection time period. The model being recursive dynamic means that capital is accumulated endogenously at a $10 \%$ rate. Investment in period $\mathrm{t}-1$ creates a new stock of capital for the period $t$. The new capital is allocated through sectors based on a capital depreciation rate and a sectoral profit rate differential from period $\mathrm{t}-1$ to $t$. Also, the dynamic model updates change of demography and technology from projected trends. Population growth $(3 \%)$ and labor supply are projected according to the estimation of the Benin national statistics office [28]. In this study, it is considered that the rates of the active labor force are constant from one year to another, i.e., the effects of education levels do not vary. A balanced macro closure is imposed; this is a 'neutral' assumption that fixes the shares government consumption and investment in absorption. The government's deficit is fixed. New and existing consumers have the same preferences.

To implement the experiments in CGE modeling, the steps illustrated in Figure 1 are followed.

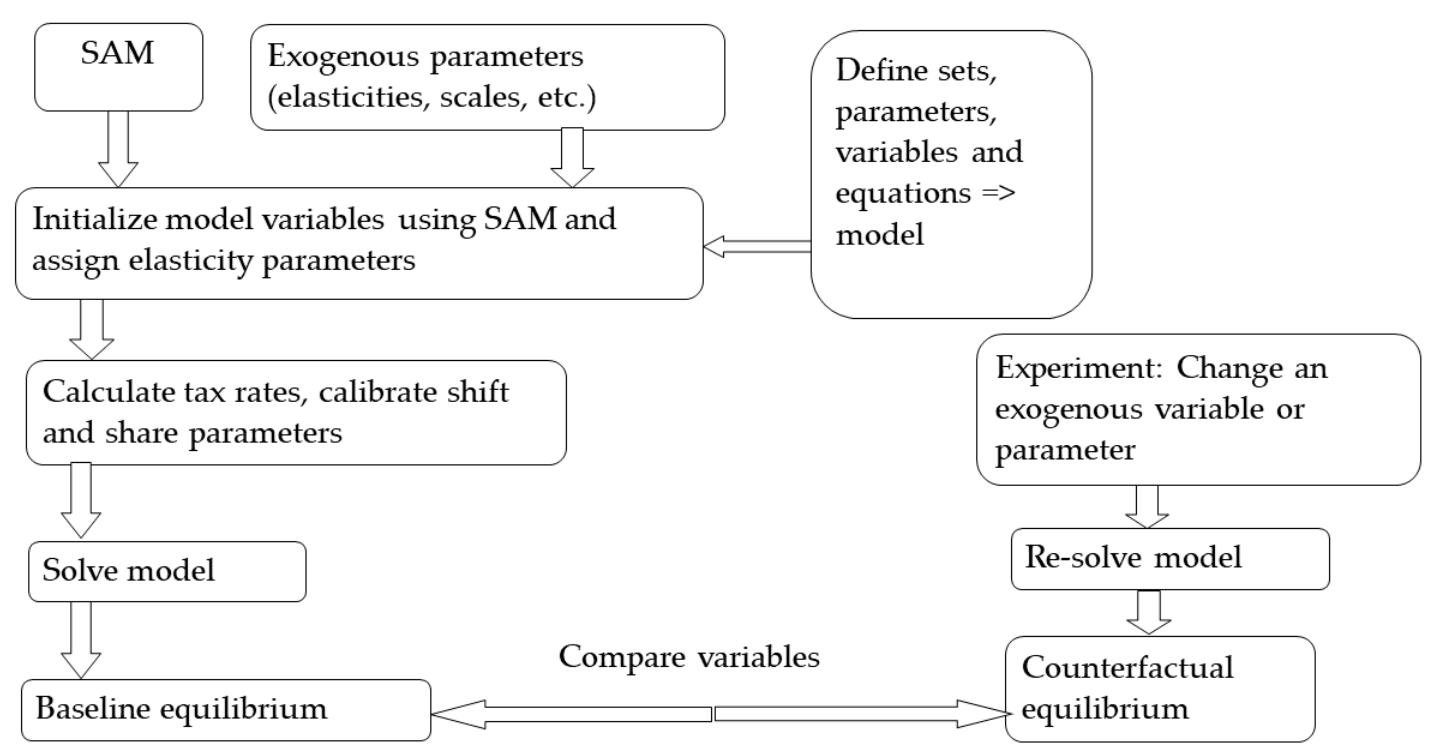

Figure 1. Different steps in running CGE experiments. Source: Adapted from Grethe et al. [29].

\subsection{Household Welfare Analysis}

The decrease in or food supply affects households. In an open market, commodity prices are often determined by the equilibrium between demand and supply. The effect of price changes on household welfare is often assessed via two concepts: the equivalent variation $(E V)$, or compensation variation $(C V)$. While the $E V$ is defined as the amount of compensation, that must be added (subtracted) to (from) household initial income, to leave that household as well off as under the combined price and 
income changes, the $C V$ is the amount of compensation, that must be added (subtracted) to (from) household final income, to leave that household as well off as before the combined price and income changes (see a review of the two concepts in [30]). In this study, the EV is used Following Chitiga and Mabugu [31], the $E V$ can be expressed as:

$$
E V=\left(P_{1}^{0} / P_{1}^{1}\right)^{\gamma}\left(P_{2}^{0} / P_{2}^{1}\right)^{1-\gamma}\left(Y^{1}-Y^{0}\right)
$$

where $P_{1}^{0}$ represents the price of good 1 in the reference scenario, $P_{1}^{1}$ represents the price of good 1 in the scenario with crop yield losses, $P_{2}^{0}$ represents the price of good 2 in the reference scenario, $P_{2}^{1}$ represents the price of good 2 in the scenario with crop yield losses, $Y^{0}$ represents the income in the reference scenario, and $Y^{1}$ represents the income in the scenario with crop yield losses.

A positive value of $E V$ implies improvement of welfare, whereas a negative value of $E V$ implies deterioration (loss) of welfare.

\subsection{Scenario Considerations}

In order to estimate the climate change-induced crop yield losses in the CGE model, the feasible generalized least squares (FGLS) method were used building on the results of Hounnou et al. [8],. Temperature and precipitation changes, as indicated by the climate projections from the Intergovermental Panel on Climate Change (IPCC) scenarios A1B and B1. The scenario IPCC scenario A1B is characterized by a quick economic growth associated with a low demographic pressure, the use of a new and more efficient technologies and a balanced emphasis on all energy sources. The IPCC scenario B1 considers a rapid economic growth as in A1, but with rapid changes towards a service and information economy, reductions in material intensity and the introduction of clean and resource efficient technologies.

To analyze the local effects of climate change for the different crops in Benin, the IPCC scenarios scenarios are considered as national references. Based on these scenarios, the crop yield losses (see Appendix A) have been estimated for six major crops in Benin with the FGLS method and introduced in the CGE model as external shocks, hence modelling the effects of climate change in terms of declining agricultural productivities. The effects of food crop yield losses are calculated as percentage changes from the baseline situation.

\subsection{Data Sources for the CGE Model}

The social accounting matrix (SAM) is the main source of data for CGE models. SAM represents the circular flows of the economy that capture all transactions and transfers between sectors and economic agents. It is a comprehensive and disaggregated picture of the socio-economic system for a delimited geographic region and in a given year. The SAM is organized in ways to interconnect how production sectors pay factors and in turn how the factor income is distributed to households. The SAM is a square matrix in which each agent in the economy, also called SAM account, is represented by a row or a column. The row records the receipts, while the column records the expenditures. To ensure consistency, the sum of all row records for an account must equal the sum of all column records for the same account The SAM used in this study is 2013 SAM for the Benin economy developed by Bennin national statistics office [32]. The SAM is disaggregated into 18 activities (i.e., 17 agricultural sector and 1 non-agricultural sector), 18 commodities (i.e., 17 agricultural copmmodities and 1 non-agricultural commodity), 3 production factors, 6 categories of households, 4 tax accounts, 1 government, 1 saving-investment, and 1 rest of the world.

Besides SAM, other data that are needed to parametrize the model include trade elasticities, production elasticities, Frisch parameter, income elasticities, etc. The list and values of these elasticities are primarily collected from existing literature [33]. 


\section{Results}

This section presents the relevant results and is divided into three subsections. The first presents changes on sectoral output due to climate change. The second analyzes the effects of climate change on sectoral import and factor remuneration. The last subsection elaborates on changes in households' welfare under climate parameter change.

\subsection{Changes in Sectoral Output Related to Climate Change}

Climate projections directly affect crop production in Benin through their influence on crop yields. Table 2 shows that simultaneous crop yield losses for the major six crops in Benin as simulated affects all sectoral outputs either in the agricultural sector or in the non-agricultural sector. By 2025, all crop output is reduced by at least one percent. The output of the main staple food crops, such as maize, rice, cassava, cowpea, yam and sorghum, falls by more than six percent by 2025. The output for export crop, except for the cashew-nut, are less affected. Cotton and pineapple outputs fall by $1.36 \%$ and $1.29 \%$, respectively.

Table 2. Effect of climate change-induced crop yield losses on total sectoral output (in \%).

\begin{tabular}{cccc}
\hline Sector & $\mathbf{2 0 2 5}$ & $\mathbf{2 0 3 5}$ & $\mathbf{2 0 4 5}$ \\
\hline Maize & -6.807 & -6.831 & -6.872 \\
Rice & -6.699 & -6.717 & -6.855 \\
Cassava & -6.872 & -6.872 & -6.872 \\
Yam & -6.872 & -6.872 & -6.872 \\
Pineapple & -1.286 & -1.591 & -1.618 \\
Vegetable & -4.958 & -6.131 & -6.234 \\
Cowpea & -6.872 & -6.872 & -6.872 \\
Sorghum & -6.824 & -6.842 & -6.872 \\
Other staple crops & -6.872 & -6.872 & -6.415 \\
Cotton & -1.359 & -1.704 & -1.734 \\
Cashew nut & -6.872 & -6.872 & -6.872 \\
Palm grove & -1.954 & -2.396 & -2.435 \\
Other export crops & -4.882 & -5.759 & -5.835 \\
Livestock & -2.642 & -3.264 & -3.318 \\
Milk processing & -2.345 & -2.883 & -2.93 \\
Poultry farming & -2.806 & -3.441 & -3.497 \\
Hunting and forestry & -2.688 & -3.343 & -3.4 \\
Fishing & -2.19 & -2.701 & -2.746 \\
Trade & -2.43 & -2.876 & -2.918 \\
Non-agricultural & -0.894 & -1.117 & -1.136 \\
\hline
\end{tabular}

Source: Authors'results.

Beyond the direct effects in the crop sector, the model results displayed in Table 2 show that animal production also declines by $2.64 \%, 2.35 \%$, and $2.81 \%$, respectively, for livestock, milk processing, and poultry farming by 2025. Hunting and forestry output is projected to fall by $2.69 \%$, while fishing output is predicted to be cut down by $2.19 \%$. The non-agricultural sector, which is not much related to climatic conditions is less affected by the simulated shock, as the non-agricultural output drops only by $0.89 \%$ by 2025 .

Beyond 2025, the same downward trend in the output of major crops (both staple and cash crops) as well as for animal production and the non-agricultural sector is observed in the projected years of 2035 and 2045 (see Table 2).

\subsection{Changes in Sectoral Exports and Imports under Climate Change Scenarios}

Apart from the sectoral output, the climate-induced yield losses affect the export supply and import demand. Figure 2 show that exports decrease by $21.22 \%, 53.25 \%, 46.79 \%$, and $17.1 \%$ for maize, 
yam, cowpea, and sorghum, respectively by 2025 . Cash crops exports also decline by $8.17 \%$ and $72.12 \%$ in 2025, respectively by 2025. This downward trend is accentuated beyond 2025, implying that if no actions are taken, sectoral exports will decline further.

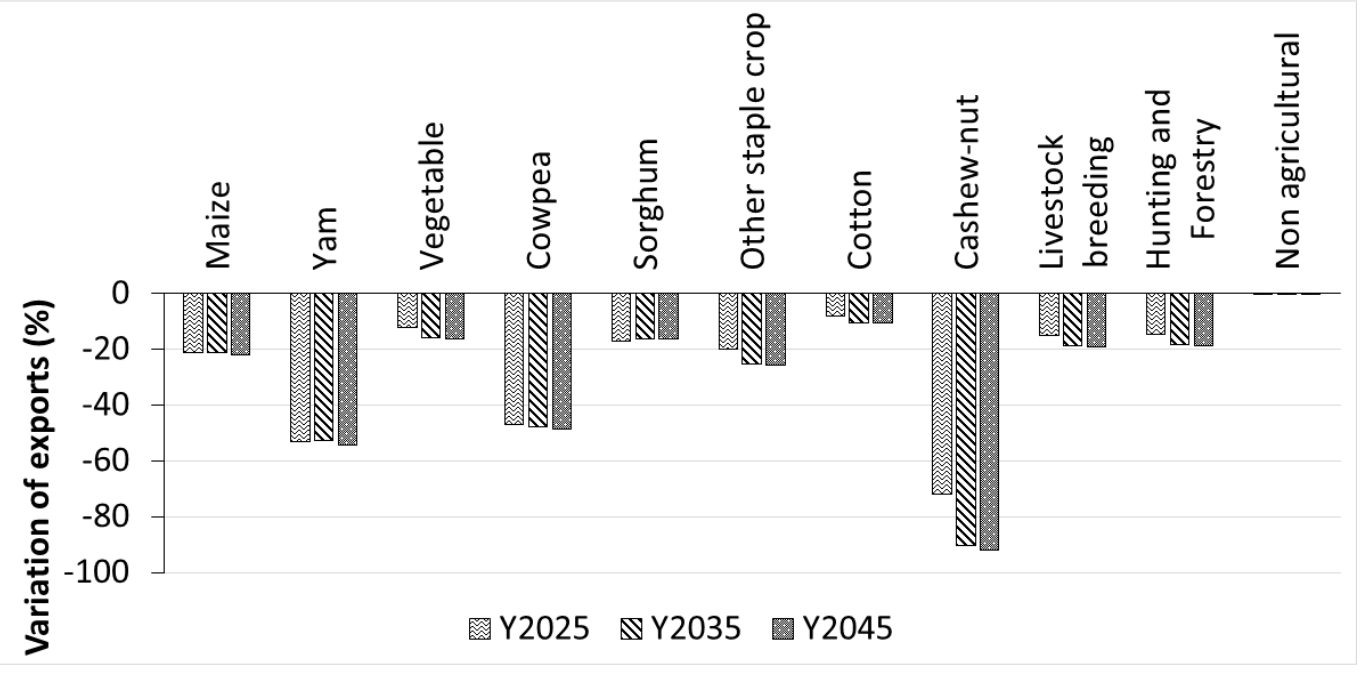

Figure 2. Effects of climate change-induced crop yield losses on sectoral exports (in \%). Source: Authors' results.

In contrast to export, import demand increases for all agricultural cmmodities (see Figure 3). For example, rice imports, vegetable imports, and sorghum imports increase by $3.51 \%, 4.89 \%$, and $7.87 \%$, respectively by 2025 . Similarly, milk imports and fish imports increase by $10.08 \%$ and $4.39 \%$, respectively by 2025. Beyond 2025, similar increases in import demand are also reported.

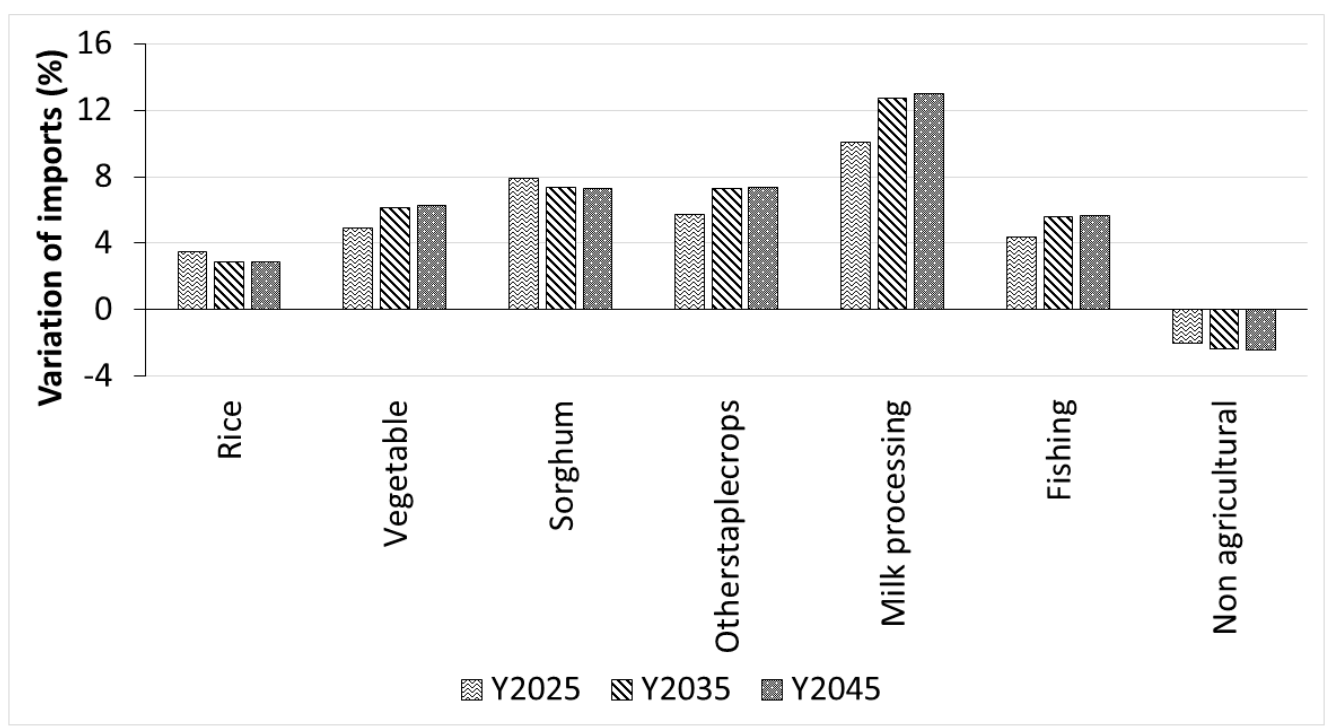

Figure 3. Effects of climate change-induced crop yield losses on sectoral imports (in \%). Source: Authors' results.

The climate-induced crop yield losses also affect domestic output sold in the domestic market as illustrated in Table 3. Maize produced domestically and sold in the domestic market is reduced by $2.79 \%, 2.91 \%$, and $2.92 \%$ in 2025,2035 , and 2045 , respectively. The quantity of domestically produced pineapple sold domestically, as an example of cash crop, decreases by $1.29 \%, 1.59 \%$, and $1.62 \%$ in 2025 , 2035 , and 2045, respectively. Similarly, domestic production of animal products sold domestically are predicted to decline by $2.21 \%$ and $2.81 \%$, respectively, for livestock breeding and poultry farming in 
2025. Domestic output of fish sold in the domestic market falls by $2.19 \%, 2.70 \%$, and $2.75 \%$ in 2025 , 2035 , and 2045, respectively.

Table 3. Effects of climate change-induced crop yield losses on the quantity of domestic output sold in the domestic markets (in \%).

\begin{tabular}{cccc}
\hline Commodities & $\mathbf{2 0 2 5}$ & $\mathbf{2 0 3 5}$ & $\mathbf{2 0 4 5}$ \\
\hline Maize & -2.790 & -2.905 & -2.915 \\
Rice & -6.699 & -6.717 & -6.855 \\
Cassava & -9.037 & -11.528 & -11.73 \\
Yam & -4.726 & -4.865 & -4.914 \\
Pineapple & -1.286 & -1.591 & -1.618 \\
Vegetable & -4.799 & -5.920 & -6.019 \\
Cowpea & -5.46 & -5.698 & -5.804 \\
Sorghum & -3.529 & -3.71 & -3.721 \\
Other staple crops & -4.542 & -5.633 & -5.729 \\
Cotton & -1.044 & -1.304 & -1.326 \\
Cashew nut & -1.923 & -2.376 & -2.415 \\
Palm grove & -1.954 & -2.396 & -2.435 \\
Other export crops & -4.882 & -5.759 & -5.835 \\
Livestock & -2.212 & -2.715 & -2.759 \\
Milk and dairy products & -2.345 & -2.883 & -2.93 \\
Poultry products & -2.806 & -3.441 & -3.497 \\
Hunting and Forestry products & -1.535 & -1.889 & -1.920 \\
Fish products & -2.190 & -2.701 & -2.746 \\
Trade products & -2.430 & -2.876 & -2.918 \\
Non-agricultural products & -1.069 & -1.313 & -1.335 \\
\hline Source: Authors' results. & & \\
\hline
\end{tabular}

Source: Authors' results.

\subsection{Changes in Factor Prices under Climate Change Scenarios}

Sectoral output changes attributed to climate-induced yield losses could lead to a direct effect on factor prices (see Figure 4). Land is the only factor which is predicted to gain value by $6.81 \%, 8.53 \%$, and $8.68 \%$ in 2025,2035 , and 2045 , respectively. On the contrary, capital remuneration is expected to fall by $5.05 \%, 6.13 \%$, and $6.23 \%$ in 2025,2035 , and 2045, respectively. About labor, unskilled labor remuneration falls slightly over the years, while skilled labor remuneration decreases sharply.

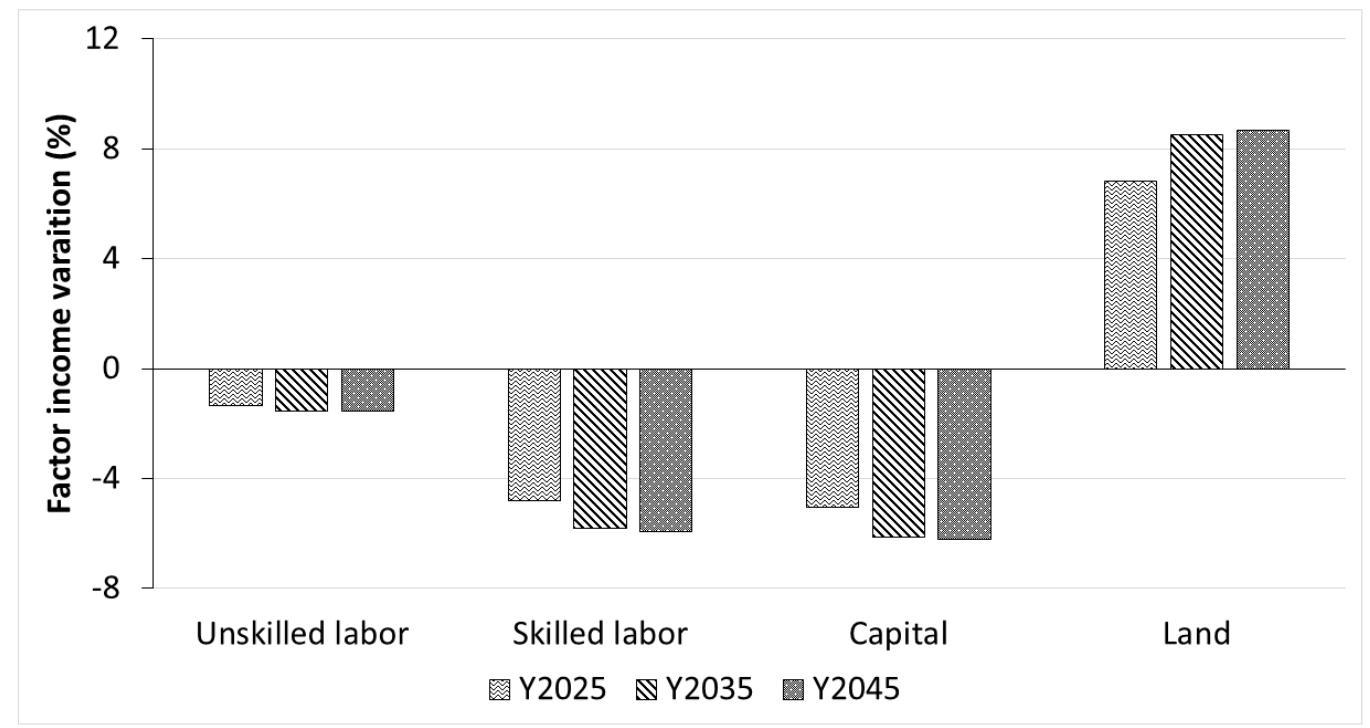

Figure 4. Changes in factor prices due to climate change-induced crop yield losses. Source: Authors' results. 


\subsection{Changes in Households Consumption, Income and Welfare}

Table 4 indicates that prices of agricultural commodities increase as a result of the crop yield losses. Considering the amplitude of climate change effects on the Beninese agricultural sector, the findings show a sharper increase in the prices of food crops compared to that of cash crops. In contrast, the price for non-agricultural commodities drops.

Table 4. Changes in commodity prices (in \%) in the scenario with crop yield losses compared to the baseline.

\begin{tabular}{cccc}
\hline Commodities & $\mathbf{2 0 2 5}$ & $\mathbf{2 0 3 5}$ & $\mathbf{2 0 4 5}$ \\
\hline Maize & 2.676 & 2.187 & 2.129 \\
Rice & 1.843 & 1.261 & 1.205 \\
Cassava & 10.176 & 14.558 & 15.707 \\
Yam & 11.9 & 11.245 & 11.324 \\
Pineapple & 2.507 & 3.212 & 3.272 \\
Vegetable & 2.199 & 2.832 & 2.885 \\
Cowpea & 10.425 & 9.792 & 10.001 \\
Sorghum & 1.271 & 0.765 & 0.711 \\
Other staple crops & 2.441 & 3.13 & 3.188 \\
Cotton & 0.517 & 0.736 & 0.753 \\
Cashew nut & 0.511 & 0.716 & 0.732 \\
Palm grove & 2.194 & 2.827 & 2.881 \\
Other export crops & 2.267 & 2.923 & 2.979 \\
Livestock & 2.444 & 3.163 & 3.223 \\
Milk and dairy products & 2.453 & 3.174 & 3.234 \\
Poultry products & 1.886 & 2.45 & 2.497 \\
Hunting and forestry products & 1.94 & 2.513 & 2.561 \\
Fish products & 1.276 & 1.682 & 1.716 \\
Non-agricultural products & -1.817 & -2.173 & -2.206 \\
\hline
\end{tabular}

Source: Authors' results.

Figure 5 indicates that household consumption decreases by 2025 for all representative household group, except the rich agricultural households. Consumption drops more for the rural household groups thatn for their urban counterparts. At the aggregate level, consumption drops, indicating a general deterioration of the household position.

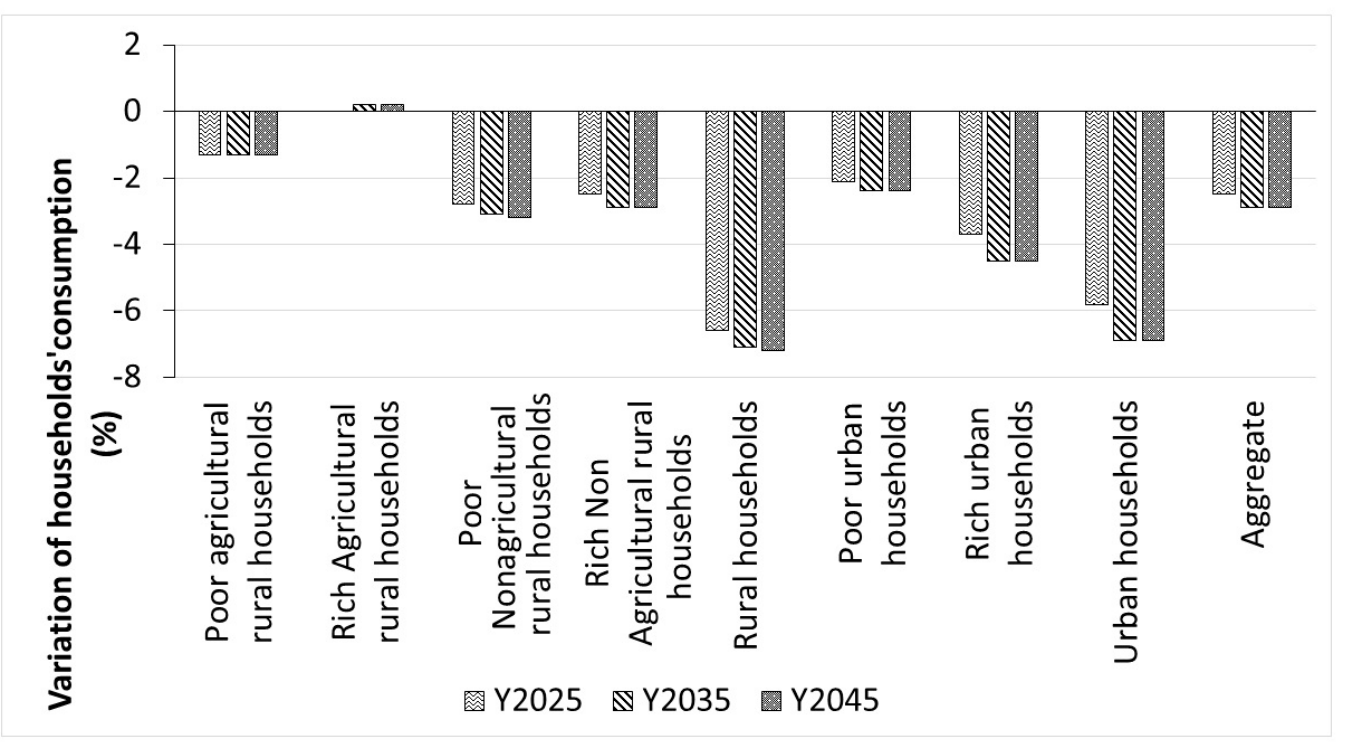

Figure 5. Changes in household consumption for different household groups under climate change-induced crop yield losses scenarios. Source: Autors' results. 
Crop yield losses lead to welfare losses (see Figure 6). The welfare of poor households declines by $1.9 \%$ and $3.4 \%$, respectively, for agricultural and non-agricultural households in rural areas by 2025; while urban poor households experience on average less welfare deterioration than their rural counterparts.

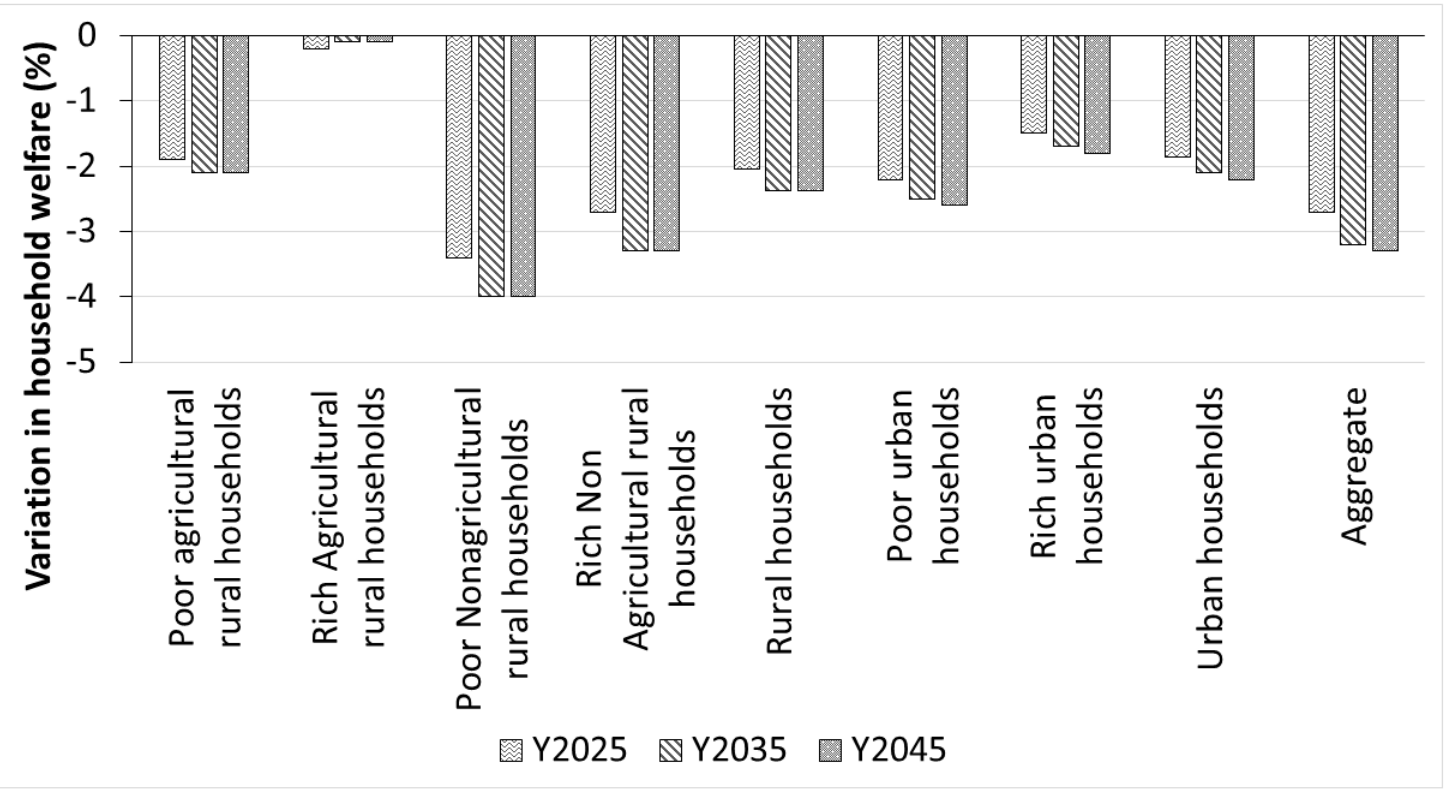

Figure 6. Effect of climate change on household welfare. Source: Authors' results.

\section{Discussion}

\subsection{Economic Sectoral Effects of Climate Change}

The results show that the climate change-induced crop yield losses trigger a decline of output in several economic sectors as well as a substantial drop in export supply. The amplitude of decline in the sectoral output is similar to that found in Nepal by Chalise et al. [6]. However, this amplitude is lower compared to that estimated for Senegal by Boccanfuso et al. [21]. The subsequent gap could be explained by an additional shock of a 50\% increase in world prices of fossil fuel that Boccanfuso et al. implemented. These results suggest that other external shocks such as an increase in world prices of fossil fuel, an increase in world prices of agricultural inputs, and political unrest would worsen the amplitude of the projected effects. As far as sectoral exports are concerned, the decline is similar to that of Kilimani et al. [34], who analyzed the economy-wide impact of drought-induced productivity losses in Uganda. With regard to the increase in sectoral imports, Juana et al. [24] also showed an increase in imports in South Africa due to water reduction scenarios. Contrary to their scenarios, the present study is focused on temperature increases and unequal distribution of precipitation as causes of crop yield losses [7,8]. Vista [25], however, found a decline in import quantity in the Philippines, suggesting that as exports decrease, imports also have to decrease in order to keep the foreign account balance unchanged. This implies a trade-off between food security and the government objective of freezing foreign borrowing to keep a sustainable deficit on the current account.

The results also demonstrate the strong linkages between agricultural and non-agricultural sectors, i.e., backward and forward linkages between the two sectors. Crop yield losses do not only lead to a decrease in total agricultural output but also to a decrease in the non-agricultural total output. This finding is consistent with that of Chalise et al. [6], who found similar results in Nepal. Moreover, Borgomeo et al. [35] showed that climate change not only has adverse influences on the agricultural sector, but also on industrial and service subsectors in Ethiopia. Arndt et al. [18] stressed that climate change effects in Ghana, extend beyond agricultural-based sectors to all other 
sectors, namely, non-agricultural sectors which include manufacturing, mining, energy, and services. It follows that policy adaptation strategies to climate change would be beneficial to agriculture and non-agricultural sectors.

\subsection{Economic Distributional Effects of Climate Change on Households' Wealth Level and According to the Living Areas}

The analysis of climate change effects has long focused on the physical aspects, but in recent years, the social effects such as the links between climate change and poverty or livelihood have received attention [36]. The results indicate that crop yield losses could lead to a decrease in households' consumption, irrespective of whether the households are poor or rich. As expected, poor households are likely to be more negatively affected than non-poor households. These findings are consistent with those of Alamgir et al. [37], who suggested that crop yield losses affect farm households by reducing their annual per capita income and therefore increasing the poverty rate in various regions across Bangladesh. Stretching the arguments, Maddison and Rehdanz [38] claimed that households from poorer and hotter areas are notably more vulnerable to climate change than those of non-poorer areas. In Benin, households from rural areas were considered in official reports as those with the highest rate of poverty [39].

The results of the study also show that rural and urban households are both adversely affected. Nevertheless, the effects are unequal from one household group to the other. Households in rural areas are arranged into poor, non-poor, agricultural, and non-agricultural groups, while in urban areas, they are arranged into poor and non-poor groups. First, the results show that poor households are more affected than non-poor households in rural areas. This finding corroborates the results of Dennig et al. [40], who reported unevenly distributed climate change effects on poor and non-poor households. However, the authors were not concerned with rural-urban considerations. Strikingly, Borgomeo et al. [35] found that climate change via precipitation reduction could benefit poor households located in drought-prone areas and who cultivate cereals. They show that rural households living in arid areas are more resilient to the climate change effects than those living in favorable agricultural areas. Second, agricultural households are less affected by climate change effects, in terms of change in consumption and in welfare, compared to non-agricultural households in rural areas. Third, the results pinpoint that non-poor households in rural areas are less affected by the climate change effects than poor households in urban areas. This is corroborated by Breisinger et al. [41], who generalized that climate change effects are unevenly distributed between rural and urban households. Chambwera et al. [42] pointed out the role of price inflation as a key driver of climate change effects in urban areas. Skoufias [43] emphasized the regressive nature of climate change effects on poor households. Fourth and last, the results indicate that rural households are more affected by climate change than urban households. In fact, poorer zones tend to have a limited adaptive capacity, such as availability and accessibility to modern technology. As households spend a higher share of their income on food, climate change effects on household conditions lead to an increase in food prices linked to a drop in food production, and decreased factor incomes. The poorest families who depend most on income from low skilled labor and activities that are more affected by climate change risks [44] experience the highest negative effects. Similar results were found by Breisinger et al. [41] who pointed out that the poorest households in both rural and urban areas are the most adversely affected by climate change. Similarly, Tol [45] showed that climate change effects reduce economic growth and drive households into poverty. Islam and Windel [36] also highlighted that the climate change effects induce a higher incidence of rural poverty compared to urban poverty.

\subsection{Implications for the Dynamic Computable General Equilibrium Model and the Economic Theory}

This study leaves some caveats for future research, especially in terms of futher model development. The model used has three limitations. The first is that the current model does not integrate the adaptive capacity of agricultural producers in the face of climate change. According to some previous research 
results [46-49], producers adapt through tentative effort strategies for a certain period of time before finding local strategies. This situation could lead to a great loss of crop yields at the beginning of the natural hazards and less when adaptation is achieved. The second limitation is that the present model does not account for the differences in climatic conditions in various agro-ecological zones of the study area. This limitation was to dfferent degree overcome in other studies $[18,23,41]$, though the challenges in considering all micro-climates are numerous. The third limitation is related to the non-agricultural sector that has been aggregated into a single account, while the agricultural sector has been disaggregated into 18 accounts. The latter limitation stem from the shortcomings of the SAM and data availability problems.

According to Tol [45], the quantification of the economic effects of climate change has no foundation in economic theory. Then, researchers resort to several consensual methods. The most common method is that household representation in the present model allows for the aggregation of micro-behaviors at macro level, an analogy that could hardly reflect the situation in the real world. The second method concern is that agricultural producers, are considered as entrepreneurs who could continuously improve their skills in order to face climate change effects following the Schumpeterian theory on the innovative aptitude of economic actors [50], who are considered passive otherwise. It appears that climate change effects on crop yields could be minored in the presence of producers' innovative practices, questioning the economic theory put to use in the process of modeling. Finally, following Ricardo's economic theory, a natural equilibrium is observed, which in reality is a series of equilibrium and disequilibrium, i.e., a continuum of equilibrium and disequilibrium leading to what is called dynamic equilibrium [51]. The choice of a recursive dynamic computable general equilibrium model accounts here for this economic assumption.

\section{Conclusions}

The results of the dynamic computable general equilibrium show that climate-induced crop yield losses could lead to a decline in domestic outputs and export supply, and an increase in import demand. In addition to climate change effects, the world price fluctuation and petrol price rising could amplify the negative effects forecasted for the Beninese agriculture. The effects of climate change affect all household groups, but poor households and rural households are the most negatively affected. Because of crop yield losses, factor incomes decrease and drive household incomes to decrease as well. Subsequently, households reduce their levels of expenditure and consumption. This leads to a household welfare loss for all household groups, but more for the poor households in rural areas. The results also show that without adaptive strategies to cope with climate change, economic growth and household welfare will decline even further in the future. In light of these results, the paper suggests that adaptation strategies are needed not only at the national level to overcome the projected negative effects on macroeconomic indicators, but also at household level to enhance the adaptative capacity of households, especially the poor households living in rural areas.

Author Contributions: Database development, F.E.H.; research management, F.E.H.; analysis and result interpretation, F.E.H., H.D., A.Z., G.B. and J.A.; model development, F.E.H. and J.A.; writing of the manuscript draft, F.E.H.; revision of the manuscript F.E.H., H.D., J.A., A.Z., and G.B.; editing of the final draft, J.A. and H.D.

Funding: This research received no external funding.

Acknowledgments: The authors thank the International Food Policy Research Institute (IFPRI) for their CGE model code. They also acknowledge Prof. Siddig Khalid, Senior Researcher at the International Agricultural Trade and Development group of Humboldt University for his support in dynamic CGE model running. Finally, the authors are grateful to Dr. Nimonka Bayale and M. Ange-Marie Codo for providing Benin's 2013 SAM data.

Conflicts of Interest: The authors declare no conflicts of interest. 


\section{Appendix A}

Table A1. Estimated crop yield losses introduced in the CGE model by projected year (in \% change).

\begin{tabular}{cccc}
\hline & $\mathbf{2 0 2 5}$ & $\mathbf{2 0 3 5}$ & $\mathbf{2 0 4 5}$ \\
\hline Maize & -4.4 & -10.0 & -13.9 \\
Rice & -9.6 & -20.9 & -28.2 \\
Cassava & -7.4 & -16.3 & -22.3 \\
Cowpea & -7.6 & -16.8 & -22.9 \\
Sorghum & -3.9 & -9.0 & -12.5 \\
Yam & -1.8 & -4.3 & 6.0 \\
\hline
\end{tabular}

\section{References}

1. IPCC. Climate Change 2013: The Physical Science Basis. In Contribution of Working Group I to the Fifth Assessment Report of the Intergovernmental Panel on Climate Change; Stocker, T.F., Qin, D., Plattner, G.-K., Tignor, M., Allen, S.K., Boschung, J., Nauels, A., Xia, Y., Bex, V., Midgley, P.M., Eds.; Cambridge University Press: Cambridge, UK; New York, NY, USA, 2013; p. 1535.

2. IPCC. Climate Change 2014: Impacts, Adaptation, and Vulnerability. In Part A: Global and SectoralAspects, Contribution of Working Group II to the Fifth Assessment Report of the IntergovernmentalPanel on Climate Change; Field, C.B., Barros, V.R., Dokken, D.J., Mach, K.J., Mastrandrea, M.D., Bilir, T.E., Chatterjee, M., Ebi, K.L., Estrada, Y.O., Genova, R.C., et al., Eds.; Cambridge University Press: Cambridge, UK; New York, NY, USA, $2014 ;$ p. 1132.

3. OECD. The Economic Consequences of Climate Change; OECD Publishing: Paris, France, 2015. [CrossRef]

4. Nelson, C.G.; Valin, H.; Sands, D.R.; Havlík, P.; Ahammad, H.; Deryng, D.; Elliott, J.; Fujimorih, S.; Hasegawa, T. Climate change effects on agriculture: Economicresponses to biophysical shocks. PNAS 2014, 111, 3274-3279. [CrossRef] [PubMed]

5. Tol, R.S.J. The Economic Effects of Climate Change. J. Econ. Perspect. 2009, 23, 29-51. [CrossRef]

6. Chalise, S.; Naranpanawa, A.; Bandara, J.S.; Sarker, T. A general equilibrium assessment of climate change-induced loss of agricultural productivity in Nepal. Econ. Model. 2017, 62, 43-50. [CrossRef]

7. Hounnou, E.F.; Dedehouanou, H. Variability of temperature, precipitation and potential evapotranspiration time series analysis in Republic of Benin. IJAER 2018, 4, 991-1019.

8. Hounnou, E.F.; Dedehouanou, H.; Zannou, A.; Bakary, S.; Mahoussi, F.E. Influence of Climate Change on Food Crop Yield in Benin Republic. JAS 2019, 11, 281-295. [CrossRef]

9. Awoye, O.H.R.; Pollinger, F.; Agbossou, E.K.; Paeth, H. Dynamical-statistical projections of the climate change impact on agricultural production in Benin by means of a cross-validated linear model combined with Bayesian statistics. Agric. For. Meteorol. 2017, 234, 80-94. [CrossRef]

10. World Bank. 2019. Available online: https://data.worldbank.org/country/benin (accessed on 5 April 2019).

11. Yegbemey, R.N.; Yabi, J.A.; Tovignan, S.D.; Gantoli, G.; Haroll Kokoye, S.E. Farmers' decisions to adapt to climate change under various property rights: A case study of maize farming in northern Benin (West Africa). Land Use Policy 2013, 34, 168-175. [CrossRef]

12. Kpadonou, B.A.R.; Adegbola, Y.P.; Tovignan, D.S. Local knowledge and adaptation to climate change in Ouémé.Valley, Benin. Afr. Crop Sci. J. 2012, 20, 181-192.

13. Sanchez, C.A.; Fandohan, B.; Assogbadjo, E.A.; Sinsin, B. A countrywide multi-ethnic assessment of local communities' perceptionof climate change in Benin (West Africa). Clim. Dev. 2012, 4, 114-128. [CrossRef]

14. Sherony, R.K.; Knowels, J.G.; Boyd, R. The Economic Impact of Crop Losses: A Computable General Equilibrium Approach. West. J. Agric. Econ. 2008, 16, 144-155.

15. Shiferaw, B.; Tesfaye, K.; Kassie, M.; Abate, T.; Prasanna, B.M.; Menkir, A. Managing vulnerability to drought and enhancing livelihood resilience in subSaharan Africa: Technological, institutional and policy options. Weather Clim. Extreme. 2014, 3, 67-79. [CrossRef]

16. Brown, C.; Meeks, R.; Ghile, Y.; Hunu, K. Is water security necessary? An empirical analysis of the effects of climate hazards on national-level economic growth. Phil. Trans. R. Soc. A 2013, 371, 20120416. [CrossRef] [PubMed] 
17. Sadoff, C.W.; Hall, J.W.; Grey, D.; Aerts, J.C.J.H.; Ait-Kadi, M.; Brown, C.; Wiberg, D. Securing Water, Sustaining Growth. Report of the GWP/OECD Task Force on Water Security and Sustainable Growth; University of Oxford: Oxford, UK, 2015.

18. Arndt, C.; Asante, F.; Thurlow, J. Implications of Climate Change for Ghana's Economy. Sustainability 2015, 7, 7214-7231. [CrossRef]

19. Bezabih, M.M.; Chambwera, J.; Stage, J. Climate change and total factor productivity in the Tanzanian economy. Clim. Policy 2011, 11, 1289-1302. [CrossRef]

20. Ananda, R.R.; Widodo, T. A General Assessment of Climate Change—Loss of Agricultural Productivity in Indonesia. MPRA Paper No. 91316. Available online: https://mpra.ub.uni-muenchen.de/91316/ (accessed on 7 January 2019).

21. Boccanfuso, D.; Savard, L.; Estache, A. The Distributional Impact of Developed Countries' Climate Change Policies on Senegal: A Macro-Micro CGE Application. Sustainability 2013, 5, 2727-2750. [CrossRef]

22. Thurlow, J.; Zhu, T.; Diao, X. Current Climate Variability and Future Climate Change: Estimated Growth and Poverty Impacts for Zambia. Rev. Dev. Econ. 2012, 16, 394-411. [CrossRef]

23. Gebreegziabher, Z.; Stage, J.; Mekonnen, A.; Alemu, A. Climate change and the Ethiopian economy: A CGE analysis. Environ. Dev. Econ. 2015, 21, 205-225. [CrossRef]

24. Juana, J.S.; Strzepek, K.M.; Kirsten, J.F. Households' welfare analyses of the impact of global change on water resources in South Africa. Agrekon 2008, 47, 309-326. [CrossRef]

25. Vista, B.A. Simulating climate-induced impacts on Philippine agriculture using computable general equilibrium analysis. J. ISSAAS 2014, 20, 16-28.

26. Armington, P.A. A Theory of Demand for Products Distinguished by Place of Production. IMF Staff Pap. 1969, 16, 159-178. [CrossRef]

27. Thurlow, J. A Recursive Dynamic CGE Model andMicrosimulation Poverty Module for South Africa; International Food Policy Research Institute: Washington, DC, USA, 2008.

28. INSAE. Synthèse des analyses sur l'état par la structure de la population. Tome 1 Répartition Spatiale, Structure par âge et par sexe, état Matrimonial et Possession d'acte de Naissance; INSAE: Cotonou, Benin, 2017; p. 20.

29. Grethe, H.; Siddig, K.; Luckmann, J. Capacity Building on Policy Analysis Using Economy-wide Models in Benin; Humboldt-Universität zu Berlin, Training material: Berlin, Germany, 2019; p. 30.

30. Badolo, F.; Traoré, F. Impact of Rising World Rice Prices on Poverty and Inequality in Burkina Faso. CERDI Etudes et Documents No 22; Ferrand: Clermont, FL, USA, 2012; p. 52.

31. Chitiga, M.; Mabugu, R. Evaluating the impact of land redistribution: A CGE microsimulation application to Zimbabwe. J. Afr. Econ. 2008, 17, 527-549. [CrossRef]

32. INSAE. National Account: Table of Integrated Economic Account and Table of Input and Output; INSAE: Cotonou, Benin, 2013.

33. Issahaku, Z.A. Climate Change, Agricultural Productivity and Poverty in Ghana's Context: Macro-micro Analysis. Ph.D. Thesis, International Development and Cooperation Hiroshima University, Hiroshima, Japan, 2015; p. 181.

34. Kilimani, N.; van Heerden, J.; Bohlmann, H.; Roos, L. Economy-wide impact of drought induced productivity losses", Disaster Prevention and Management. Disaster Prev. Manag. Int. J. 2018, 27, 636-648. [CrossRef]

35. Borgomeo, E.; Vadheim, B.; Woldeyes, B.F.; Alamirew, T.; Tamu, S.; Charles, K.; Kebede, S.; Walker, O. The Distributional and Multi-Sectoral Impacts of Rainfall Shocks: Evidence From Computable General Equilibrium Modelling for the Awash Basin, Ethiopia. Ecol. Econ. 2018, 146, 621-632. [CrossRef]

36. Islam, N.; Windel, J. Climate Change and Social Inequality; Paper No. 152 ST/ESA/2017/DWP/152; Department of Economic \& Social Affairs Working: New York, NY, USA, 2017; p. 32.

37. Alamgir, S.M.; Furuya, J.; Kobayashi, S.; Binte, M.R.; Salam, A.M. Farmers' Net Income Distribution and Regional Vulnerability to Climate Change: An Empirical Study of Bangladesh. Climate 2018, 6, 65. [CrossRef]

38. Maddison, D.; Rehdanz, K. The impact of climate on life satisfaction. Ecol. Econ. 2011, 70, 2437-2445. [CrossRef]

39. INSAE (Institut National de la Statistiqueet de l'AnalyseEconomique); PAM (World Food Program); MAEP (Benin Ministry of Agriculture, Livestock and Fisheries). Analyse Globale de la Vulnérabilité et de la Sécurité Alimentaire. Available online: http://www.insae-bj.org/autres_enquetes.html?file=files/ enquetesrecensements/autres/Benin_AGVSA_Rapport (accessed on 4 December 2018). 
40. Dennig, F.; Budolfson, B.M.; Fleurbaey, M.; Siebert, A.; Socolow, H.R. Inequality, climate impacts on the future poor, and carbon prices. PNAS 2015, 112, 15827-15832. [CrossRef]

41. Breisinger, C.T.; Zhu, P.; Al Riffai, G.; Nelson, R.; Robertson, J. Funes, and Verner, D. Global and Local Economic Impacts of Climate Change in Syria. Clim. Chang. Econ. 2013, 4, 1350001. [CrossRef]

42. Chambwera, M.; Heal, G.; Dubeux, C.; Hallegatte, S.; Leclerc, L.; Markandya, A.; McCarl, B.A.; Mechler, R.; Neumann, J.E. Economics of adaptation. In Climate Change 2014: Impacts, Adaptation, and Vulnerability. Part A: Global and Sectoral Aspects. Contribution of Working Group II to the Fifth Assessment Report of the IPCC; Field, C.B., Barros, V.R., Dokken, D.J., Mach, K.J., Mastrandrea, M.D., Bilir, T.E., Chatterjee, M., Ebi, K.L., Estrada, Y.O., Genova, R.C., et al., Eds.; Cambridge University Press: Cambridge, UK; New York, NY, USA, 2014; pp. 945-977.

43. Skoufias, E. The Poverty and Welfare Impacts of Climate Change: Quantifying the Effects, Identifying the Adaptation Strategies; World Bank: Washington, DC, USA, 2012.

44. Al-Haboby, A.; Breisinger, C.; Debowicz, D.; El-Hakim, H.A.; Ferguson, J.; Telleria, R.; van Raheenen, T. Agriculture for Development in Iraq? Estimating the Impacts of Achieving the Agricultural Targets of the National Development Plan 2013-2017 on Economic Growth, Incomes, and Gender Equality; Discussion Paper 01349; IFPRI: Washington, DC, USA, 2014; p. 28.

45. Tol, S.J.R. The Economic Impacts of Climate Change. Rev. Environ. Econ. Policy 2018, 1-22. [CrossRef]

46. Deressa, T.T.; Hassan, R.M.; Ringler, C.; Alemu, T.; Yusuf, M. Determinants of farmers' choice of adaptation methods to climate change in the Nile basin of Ethiopia. Glob. Environ. Chang. 2009, 19, 248-255. [CrossRef]

47. Deressa, T.T.; Hassan, R.M.; Ringler, C. Perception of and adaptation to climate change by farmers in the Nile basin of Ethiopia. J. Agric. Sci. 2011, 149, 23-31. [CrossRef]

48. Adimassu, Z.; Kessler, A. Factors affecting farmers' coping and adaptation strategies to perceived trends of declining rainfall and crop productivity in the central Rift valley of Ethiopia. Environ. Syst. Res. 2016, 5, 1-16. [CrossRef]

49. Le Dang, H.; Li, E.; Bruwer, J.; Nuberg, I. Farmers' perceptions of climate variability and barriers to adaptation: Lessons learned from an exploratory study in Vietnam. Mitig. Adapt. Strateg. Glob. Chang. 2014, 19, 531-548. [CrossRef]

50. Swedberg, R.; Joseph, A. Schumpeter, His Life and Work; Policy press in association with Blackwell Publishers: Oxford, UK, 1991; p. 304.

51. Carvale, A.G.; Tosato, A.D. Ricardo and the Theory of Value Distribution and Growth; Routledge: London, UK, 1980; p. 256.

(C) 2019 by the authors. Licensee MDPI, Basel, Switzerland. This article is an open access article distributed under the terms and conditions of the Creative Commons Attribution (CC BY) license (http://creativecommons.org/licenses/by/4.0/). 